\title{
A tudásalapú társadalom és gazdaság kutatás-fejlesztési és innovációs súlypontjai Magyarországon
}

A kiélezett globalizációs verseny olyan kihívásokat jelent, amelyekkel a világ valamennyi, a tudásvezérelt gazdaság kiépítésében érdekelt országának szembe kell néznie. A magyar gazdaságnak és társadalomnak a tudáson és az innováción alapuló, új minőségủ fejlődési pályára kell lépnie. Nemzetközi összehasonlításban Magyarország innovációs teljesítménye alapján az EU-tagországok középmezőnyében foglal helyet, a felzárkózó országok között. Magyarországon 2003-ban megkezdődött az innovációs rendszer átfogó reformja. A jelenleg társadalmi egyeztetés alatt levő középtávú kormányzati kutatás-fejlesztési és innovációs stratégia a magyar gazdaság versenyképességének növelését szolgálja. A nemzeti innovációs rendszer elemei területileg egyenlőtlenül fejlettek, ezért a jövőben kiemelt figyelmet kell fordítani a régiók innovációs képességének növelésére.

Kulcsszavak: tudásvezérelt gazdaság, innovációs teljesitmény, versenyképesség, regionális innovációs képességek

\section{Szerzői információ:}

Imre József

Kohómérnök, a miskolci Nehézipari Egyetemen végzett, s ugyanitt szerezte meg egyetemi doktori fokozatát. 1987 óta a műszaki tudományok kandidátusa, 1998-ban PhD-fokozatot szerzett. 2003-tól egyetemi magántanár. 1983-ban tudományos ösztöndíjjal részt vett a stockholmi Királyi Mûszaki Egyetem Fémalakítási Intézetének munkájában. Japánban elvégezte az Association for Overseas Technical Scholarship kurzusát. 1993-ban kétéves angol nyelvú posztgraduális képzés keretében megszerezte az Oxford Brookes University menedzserdiplomáját. 1970 és 1987 között a Miskolci Egyetem tanársegédje, majd adjunktusa, 1987 és 1992 között a Kốbányai Könnyúfémmú innovációs vezetôje volt. 1993-tól főosztályvezetốként az Országos Múszaki Fejlesztési Bizottságnál (majd ennek jogutódjánál) dolgozott, jelenleg a Nemzeti Kutatási és Technológiai Hivatal munkatársa. Feladatai közé tartozik a kormányzati $\mathrm{K}+\mathrm{F}$ és innovációs stratégia kidolgozásának és végrehajtásának koordinálása, az EU strukturális alapjainak fogadását elókészítő munkálatokban való részvétel, továbbá az OECD tudomány- és technológiapolitikai kapcsolataiban a magyar koordinációs feladatok ellátása. Több szakmai és civil testület munkájában múködik közre, hazai és nemzetközi TéT-konferenciákat szervez és koordinál. Munkája mellett rendszeresen végez egyetemi oktatói tevékenységet is. Számos tudományos és szakmai bizottság tagja (ME Doktori Bizottsága, MTA Metallurgiai Bizottsága, Magyar Mérnökakadémia, Magyar Anyagtudományi Egyesület, NOVOFER Alapítvány, OTKA Bizottság).

E-mail: jozsef.imre@nkth.gov.hu 


\section{Lippényi Tivadar}

Gépészmérnök, a Budapesti Múszaki Egyetemen végzett, majd tudományos ösztöndíjjal a kanadai Carleton Egyetemen tanult tovább. A fizikai optika és a múszertechnika szakterületén doktorált. 1973-tól a Központi Fizikai Kutatóintézetben, majd 1984-tó1 a Tungsram Rt.-nél dolgozott különbözố beosztásokban. 1987-tôl a Tungsram Rt. lézertechnikai leányvállalatának igazgatója, majd 1989-tól 1991-ig a Tungsram Lézertechnikai Kft. ügyvezető igazgatója. 1992-tól a Kockázat Nemzetközi Befektetési Tanácsadó Rt. vezetố tanácsadója. További munkahelyei, ahol igazgatóként vagy felső vezetốként dolgozott: Pólus Rt., INNOSTART Nemzeti Üzleti és Innovációs Központ, Innolt Fejlesztő és Tanácsadó Kft., 2002-tól a Miniszterelnöki Hivatalban a Stratégiai Elemző Központ Innovációs Fốosztályán főosztályvezetô. 1998-tól 2000-ig az Európai Üzleti és Innovációs Központok Hálózatának $(E B N)$ igazgatósági tagja, majd az $E B N$ igazgatóságából létrehozott Executive Committee tagja. 1997 óta a Vállalkozói Inkubátorok Szövetségének társelnöke. 1996 óta a Magyar Innovációs Szövetség elnökségének tagjaként az Innovatív Szolgáltatások és Vállalkozások Tagozatát vezeti.

E-mail: tivadar.lippenyi@nkth.gov.hu

\section{Peredy Zoltán}

Vegyészmérnök és gazdasági mérnök, a Budapesti Múszaki Egyetemen szerezte meg diplomáit. A Richter Gedeon Gyógyszervegyészeti Gyár Szerves Vegyipari Kutatóintézetében, majd az MTA Kémiai Kutató Intézetében dolgozott tudományos munkatársként. Közben egy évet a Massachusettsi Egyetemen töltött kutatómunkával. A polimerfizika szakterületén doktorált. 1994-tól az Országos Múszaki Fejlesztési Bizottságnál részt vett a magyar tudományos és technológiai (TéT) attaséi rendszer koordinálásában, majd a Tudomány és Technológiapolitikai Kollégium Titkárságának ügyeit vitte. 2002 óta az OMFB jogutódjának (2004-tól Nemzeti Kutatási és Technológiai Hivatal) Stratégiai Foóosztályán dolgozik. Feladata a kormányzati K + F és innovációs stratégia kimunkálásában és végrehajtásában való részvétel, a közfinanszírozású $\mathrm{K}+\mathrm{F}$ programok értékelésében való közremúködés, valamint az NKTH részéról a regionális innovációs ügyek koordinálása.

E-mail: zoltan.peredy@nkth.gov.hu

\section{Így hivatkozzon erre a cikkre:}

Lippényi Tivadar, Imre József, Peredy Zoltán. „A tudásalapú társadalom és gazdaság kutatás-fejlesztési és innovációs súlypontjai Magyarországon”.

Információs Társadalom VI, 3. szám (2006): 40-53.

$=$ https://dx.doi.org/10.22503/inftars.VI.2006.3.3

A folyóiratban közölt müvek

a Creative Commons Nevezd meg! - Ne add el! - Így add tovább! 4.0

Nemzetközi Licenc feltételeinek megfelelöen használhatók. 
Lippényi Tivadar - Imre József - Peredy Zoltán

(Nemzeti Kutatási és Technológiai Hivatal)

\section{A tudásalapú társadalom és gazdaság kutatás-fejlesztési és innovációs súlypontjai Magyarországon}

A társadalmi jólét alapja a gazdaság versenyképessége és a társadalom kohéziója. A versenyképes gazdaságot az innováció, a kreativitás, a kockázatvállalás és a környezeti-természeti eróforrások fenntartható használata jellemzi, ami új vállalkozások alapításában, beruházásokban, továbbá versenyképes termékek, szolgáltatások és eljárások kifejlesztésében valósul meg. A tudásvezérelt gazdaság megteremtése a kiélezett globalizációs versenyben természetesen számos olyan kihívást is jelent (robbanásszerú tudományos és technológiai fejlôdés, új együttmúködési formák és hálózatok kialakulása, regionális egyenlő́tlenségek, $\mathrm{K}+\mathrm{F}$ strukturális aránytalanságok létrejötte, a K + F területén az állami szerepvállalás újragondolása, új versenytényezók és szabályok felbukkanása), amelyekkel az EU valamennyi tagállamának szembe kell néznie.

A magyar gazdaságnak és társadalomnak a tudáson és az innováción alapuló, új minôségú fejlődési pályára kell lépnie. Arra kell törekedni, hogy Magyarország ne az alacsony bérekre építve, hanem innovatív és tudásintenzív tevékenységekkel, a lehetố legnagyobb hozzáadott értéket termelő szinten kapcsolódjon be a világgazdaságba. A magyar gazdaság tartós fejlődése csak az innovációt ösztönzô környezetben valósulhat meg.

\section{A magyar $K+F$ és innováció helyzete}

a) Helyzetelemzés a $\mathrm{K}+\mathrm{F}$ és innováció területén

2004-ben Magyarországon a nemzeti szintű $\mathrm{K}+\mathrm{F}$ tevékenységekre fordított kiadás 181,5 milliárd Ft volt. Ez a GDP 0,89\%-át jelenti (1. ábra), míg az EU átlaga 1,9\%. A gondot az okozza, hogy a hazai $\mathrm{K}+\mathrm{F}$ finanszírozás szerkezete aránytalan, alacsony a vállalatok részesedése. A magyar GDP-re vetített állami ráfordítás a $\mathrm{K}+\mathrm{F}$ területén $0,46 \%$, ami az EU átlagának $(0,67 \%)$ több mint háromnegyede. Ezzel szemben az üzleti szféra GDP-arányos $\mathrm{K}+\mathrm{F}$ ráfordítása magyar viszonylatban $0,33 \%$, és ez az EU-átlag $(1,07 \%)$ egyharmadát sem éri el. A 2. ábra az EU-tagországok teljes nemzeti, valamint üzleti $\mathrm{K}+\mathrm{F}$ ráfordításainak (Gross Expenditure on $R$ \& $D, G E R D$, illetve Business Expenditure on $R$ \& $D, B E R D$ ) értékét mutatja be a GDP százalékában, a 2001-tól 2003-ig terjedő időszakra. 


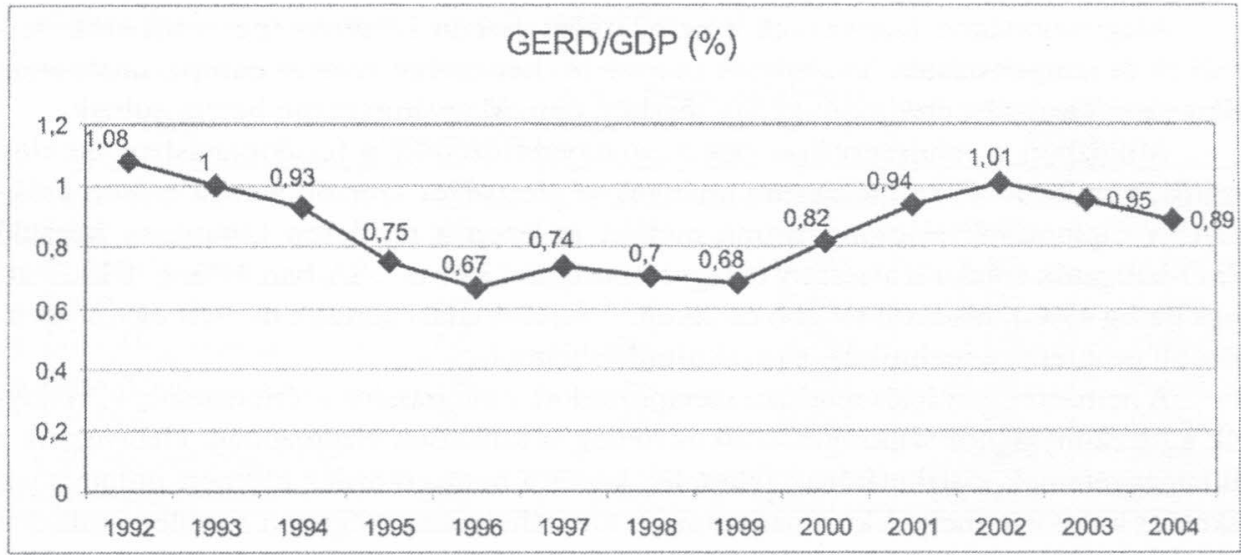

1. ábra. A K + F ráfordítások aránya a GDP-hez viszonyítva Magyarországon (\%) Forrás: KSH.

A 2. ábra jól mutatja Magyarország kedvezôtlen helyzetét, különösen az állami és a vállalati $\mathrm{K}+\mathrm{F}$ ráfordítások arányát illetően.

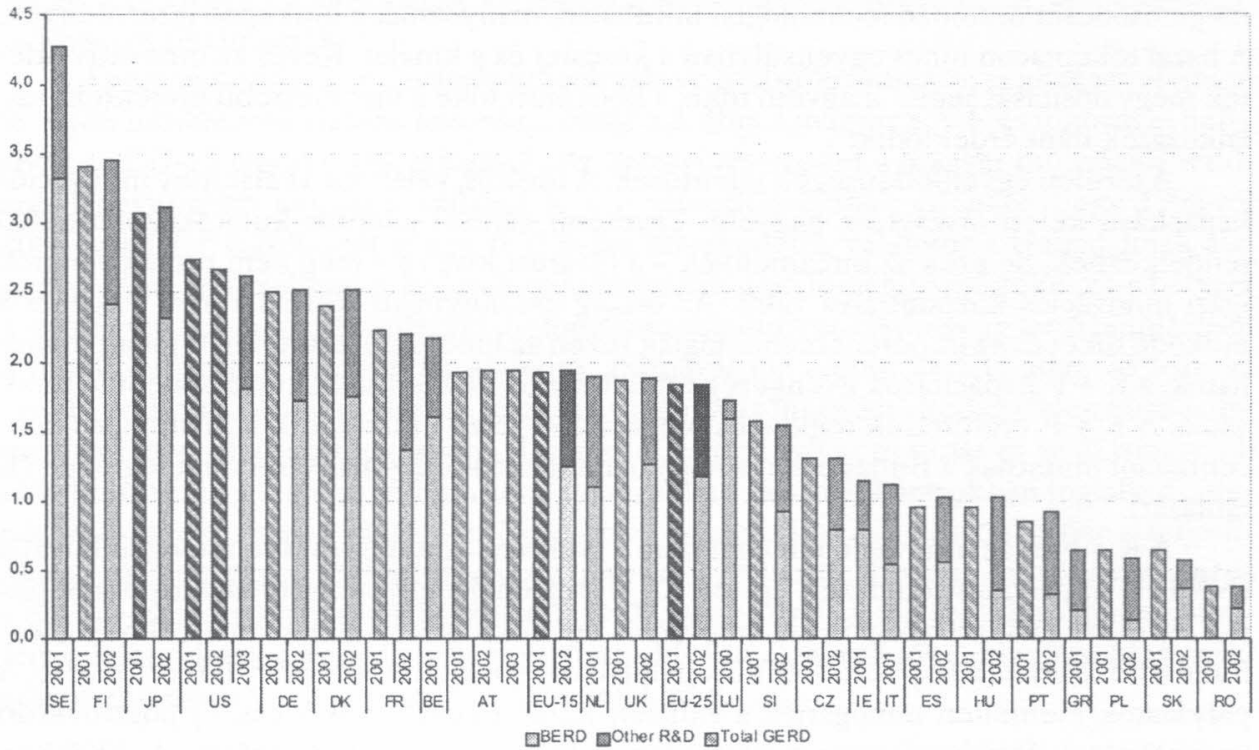

2. ábra. Az EU-tagországok teljes nemzeti, valamint üzleti $\mathrm{K}+\mathrm{F}$ ráfordításainak (GERD és $B E R D$ ) értékei a GDP százalékában (2001-2003) 
Magyarországon hiányoznak a nemzetközi piacon versenyképes vállalatok, termékek és szolgáltatások. A vállalatok innovációs képessége jóval az európai uniós átlag alatt van. A kutatási eredmények így részben nem Magyarországon hasznosulnak.

Miközben a rendszerváltás óta megnégyszereződött a felsốoktatásban tanulók száma, a múszaki és természettudományos végzettséget szerzók aránya erôsen csökken. A diplomások alacsony száma mellett az ezen a területen kutatónak készülő PhD-hallgatók aránya is alacsony (Magyarországon 13\%, az USA-ban 41\%, az EU-25 átlaga pedig 49\%,), ráadásul tovább csökken. A felsóoktatási gondok mellett egyre jelentősebb probléma a technikus- és szakmunkáshiány is.

A nemzeti innovációs rendszer szétaprózódott, erőforrásaink szétforgácsoltak. Hiányzik a hatékonysághoz szükséges kritikus tömeg, a kutatások elaprózottak. Hiányoznak a kutatóegyetemek kialakulásának feltételei, kevés a nemzetközileg elismert tudományos iskola és kutatói múhely. A közfinanszírozású kutatóhelyeken elégtelen a szellemi tulajdon védelme és hasznosítása. Nem teremtődtek meg a tudástranszfer feltételei. A kedvezốtlen jogszabályi környezet miatt a közfinanszírozású kutatóhelyeken akadályokba ütközik az onnan induló (spin-off) vállalkozások alapítása. Az interszektorális és nemzetközi kutatói mobilitás nagyon alacsony szintú. A megfelelő kutatói mobilitáshoz, valamint a külföldön dolgozó, tehetséges magyar szakemberek hazatéréséhez és itthoni megfelelố szintư munkavállalásához szükséges vállalati, egyetemi és akadémiai háttér nem elég erôs.

A kutatásimúszer-állomány elöregedett, fokozódó lemaradás érzékelhetô a modern kutatási infrastruktúra területén is. Fejletlen az innovatív KKV-k alapítását és megerôsödését ösztönzố technológiai inkubáció, hiányoznak a hídképző intézmények. A hazai tókepiacon nincs egyensúlyban a kereslet és a kínálat. Kevés az innovatív ötletek megvalósítását segítố magvetô tôke, a kockázati tóke a már érettebb projektek, vállalkozások iránt érdeklődik.

A területi egyenlốtlenségek jelentôsek. A fớváros, valamint az alacsony innovációs kapacitású keleti országrész nagyobb egyetemi városai jelentốs kutatóközpontokkal rendelkeznek, de ezek az intézmények - a fővárost kivéve - még nem tudtak a régiók igazi innovációs központjaivá válni. Az ország északnyugati része sikerrel vonzotta a múködő tốkét és az importált technológiák révén az innováció feltételei itt jónak mondhatók, a $\mathrm{K}+\mathrm{F}$ kapacitások gyengesége miatt mégis kevés a saját kutatásra épüló innováció. $\mathrm{A} \mathrm{K}+\mathrm{F}$ erőforrások regionális megoszlását jelzố indikátorok kétharmados koncentrációt mutatnak a Budapestet is magában foglaló közép-magyarországi régióban (1. táblázat).

A K + F és az innováció támogatására a Nemzeti Kutatási és Technológiai Hivatal (NKTH) új pályázati rendszert épített ki. Új regionális egyetemi tudásközpontok jöttek létre. Megalakult a regionális innovációs ügynökségek hálózata, amelyeknek a legfontosabb feladata a régiók kis-és középvállalkozásainak innovációra való ösztönzése. A pályázatok kiemelten támogatják a vállalati-kutatói együttmúködést, új posztdoktori munkahelyek létrehozását és a külföldön dolgozó kutatók hazatérését. A 2005-ben meghirdetett pályázatoknak köszönhetően 29 külföldön dolgozó kutató tért haza. Egyszerúsödött a korábbi pályázati rendszer, és nagy szakmai tekintélyú külföldi szakértốk alkalmazásával bevezették a nemzetközi bíráltatási gyakorlatot. Megindult az elektronikus pályázati rendszerre való átállás. Kormányzati kutatás-fejlesztési megállapodások eredményeként létrejött egy magyar-német és egy magyar-orosz kutatólaboratórium. 
1. táblázat. A K + F erôforrások regionális megoszlása (2004)

\begin{tabular}{|l|c|r|r|r|r||}
\hline \multicolumn{1}{|c|}{ Terület } & $\begin{array}{c}\text { A K + F he- } \\
\text { lyek száma }\end{array}$ & $\begin{array}{c}\text { A K + F-ben foglalkozta- } \\
\text { tottak átszámított létszáma } \\
\text { (fó) }\end{array}$ & $\begin{array}{r}\text { A K + F ráfordításai (millió } \\
\text { Ft) }\end{array}$ \\
\hline \hline 1. Közép-Magyarország & 1255 & 14741 & $(64,6 \%)$ & 116692 & $(64,3 \%)$ \\
\hline 2. Közép-Dunántúl & 158 & 1206 & $(5,3 \%)$ & 10820 & $(6,0 \%)$ \\
\hline 3. Nyugat-Dunántúl & 194 & 895 & $(3,9 \%)$ & 8225 & $(4,5 \%)$ \\
\hline 4. Dél-Dunántúl & 227 & 1244 & $(5,4 \%)$ & 5773 & $(3,2 \%)$ \\
\hline 5. Észak-Magyarország & 145 & 1067 & $(4,7 \%)$ & 4729 & $(2,6 \%)$ \\
\hline 6. Észak-Alföld & 280 & 1763 & $(7,7 \%)$ & 14761 & $(8,1 \%)$ \\
\hline 7. Dél-Alföld & 282 & 1910 & $(8,4 \%)$ & 11896 & $(6,6 \%)$ \\
\hline Területileg nem besorolható & & & & 8629,4 & $(4,8 \%)$ \\
\hline Magyarország összesen & 2541 & 22826 & $(100 \%)$ & 181525,4 & $(100 \%)$ \\
\hline
\end{tabular}

\section{a) A magyar KFI helyzete az Európai Unióban}

Annak érdekében, hogy az EU viszonyítani tudja helyzetét két fő versenytársához, az USA-hoz és Japánhoz képest, és össze tudja hasonlítani az egyes tagországok nemzeti innovációs rendszerének teljesítményét, évente megjelenik az EU Innovációs Eredménytábla (Innovation Scoreboard) címú kiadványa. Ennek összeállításához, az innovációs rendszerek és folyamatok vizsgálatára az összehasonlító elemzés (benchmarking) ${ }^{1}$ módszerét alkalmazzák.

Az egyes országok innovációs teljesítménye többféle indikátor segítségével írható le. Ilyen indikátorok alapján hasonlítja össze a 3. ábra a magyar $\mathrm{K}+\mathrm{F}$ és innováció helyzetét az EU-15 tagországok átlagával. Az összevetés szerint a magyar innovációs rendszer leggyengébb pontjai a vállalati $\mathrm{K}+\mathrm{F}$ ráfordítás (annak ellenére, hogy 1998-tól 2004-ig a GDP 0,26\%-áról annak 0,33\%-ára növekedett), valamint a szabadalmak alacsony száma és a szellemi tulajdon hasznosításának nem kielégítô mértéke. Ez a helyzet a természettudományi és múszaki diplomások, valamint az élethosszig tartó tanulásban, a felnôttképzésben résztvevoók alacsony számával (az elóbbi az EU átlag 33\%-át, az utóbbi pedig az EU-átlag 46\%-át teszi ki), továbbá az innováció kedvezốtlen társadalmi megítélésével áll összefüggésben. Hazánk teljesítménye az új tudás és az új ismeretek elôállítása terén a legjobb. A high-tech iparágakban és szolgáltatásokban foglalkoztatottak arányát tekintve - a külföldi múködốtóke-beruházásoknak köszönhetốen - teljesítményünk megfelel az EU-átlagnak. Az innovatív szellemú, újonnan induló (start-up) és a $\mathrm{K}$ + F eredmények hasznosítására létrejövố (spin-off) vállalatok számára azonban problémát jelent, hogy a korai fázisba befektetni kívánó magvetô tóke jelenléte Magyarországon mindössze az EU-átlag 6\%-ának felel meg.

${ }^{1}$ A benchmarking elemzési technika arra használható, hogy a belsố teljesítményt összehasonlítsuk a „legjobb” külsố teljesítménnyel, és azonosítsuk az erôsségeket és gyengeségeket. A benchmarking folyamatosan feltárhatja a jó gyakorlatokat, s ez az ismeret a teljesítmény további javítására használható. Legfontosabb módszere a konkrét mutatószámok (indikátorok) közvetlen összehasonlítása és elemzése. A teljesítményértékek azt fejezik ki, hogy miben és mennyivel jobb az egyik teljesítmény a másiknál. 


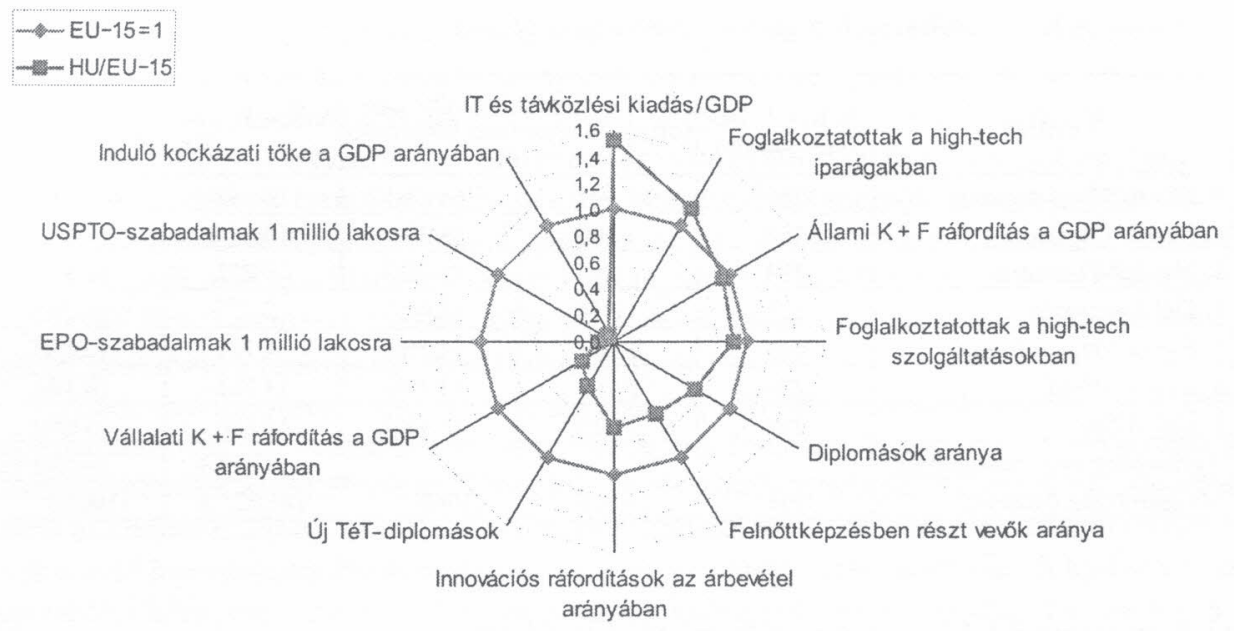

3. ábra. Magyarország innovációs mutatószámai az EU-15 országok hasonló indikátoraihoz viszonyítva

Az egyes országok nemzeti innovációs rendszereinek összesített teljesítménye többféle indikátorcsoport segítségével írható le. Az indikátorcsoportokból komplex indikátorok alakíthatók ki, amelyeknek a segítségével rangsorolható az országok innovációs teljesítménye. Az EU Innovációs eredménytábláján (Innovation Scoreboard) a különbözó indikátorokból súlyozó faktorok segítségével állítják elố az ún. összesített innovációs indexet (Summary Innovation Index, SII). Az SII-t két fố indikátorcsoportból, az innovációs input és az innovációs output indikátoraiból állítják elő.

Az innovációsinput-indikátorok három alcsoportra oszthatók:

- Az innováció hajtóerejét mérö indikátorok az innovációs potenciál szervezeti feltételeinek mérésére szolgálnak (ilyen indikátor a természettudományi és múszaki végzettségúek aránya a 20-29 éves populációban, a felsốoktatásban részt vevốk aránya, az élethosszig tartó tanulásban résztvevoók aránya, valamint a háztartások és a vállalkozások internet-hozzáférésének az aránya is).

- Az ismeretek elóállítását méró indikátorok a sikeres tudásalapú gazdaság emberi erôforrásaiba történố befektetéseket jelzik (az állami költségvetés, illetve a vállalatok $\mathrm{K}+\mathrm{F}$ kiadásai a $G D P \%$-ában).

- Az innovativitást és a vállalkozási hajlandóságot méró indikátorok mikroökonómiai szinten jelzik az innovációs erőfeszítéseket [ilyen indikátor többek között az innovatív kis- és középvállalkozások (KKV-k) aránya az összes KKV-hez viszonyítva, a más cégekkel kooperáló innovatív KKV-k aránya, az innovációra fordított összes kiadás a vállalati árbevétel arányában, a korai fázisú kockázati tôke a $G D P$ \%-ában, az IKT-ra fordított össz-kiadás a GDP \%-ában, valamint a nem technológiai jellegú innovációt megvalósító KKV-k aránya]. 
Az innovációsoutput-indikátorokat két alcsoportra szokás felosztani:

- A tudás alkalmazását méró indikátorok az innovációs rendszer teljesítményét mérik a magas hozzáadott értéket termelő szektorokban (ilyen indikátor például a high-tech szektorban és szolgáltatásokban alkalmazottak aránya a foglalkoztatottak összlétszámához viszonyítva, a piacon új termékek eladásából származó bevétel aránya a vállalati árbevételeken belül, továbbá a vállalat számára új termékek eladásából származó bevétel részaránya az összes vállalati árbevételben).

- A szellemi tulajdon hasznositását méró indikátorok a high-tech szektorban a sikeres know-how-k számán keresztül mérik az elért eredményeket (idetartozik az új EPO-, USPTO- és triád szabadalmak száma egymillió fős népességre vetítve, valamint az új high-tech EPO-, USPTO- és triád szabadalmak száma, hasonló viszonylatban).

Az összesített indikátor előállításánál két fố szempont játszik szerepet: a politikai relevancia követelményének kielégítéséhez megfelelő információt kell tartalmaznia a döntéshozók számára döntéseik meghozatalához, továbbá alkalmasnak kell lennie az adott folyamatok formalizált módon történó leírására. A 4. ábra a legújabb összesített innovációs index $(S I I, 2005)$ alapján mutatja be hazánk relatív helyzetét.

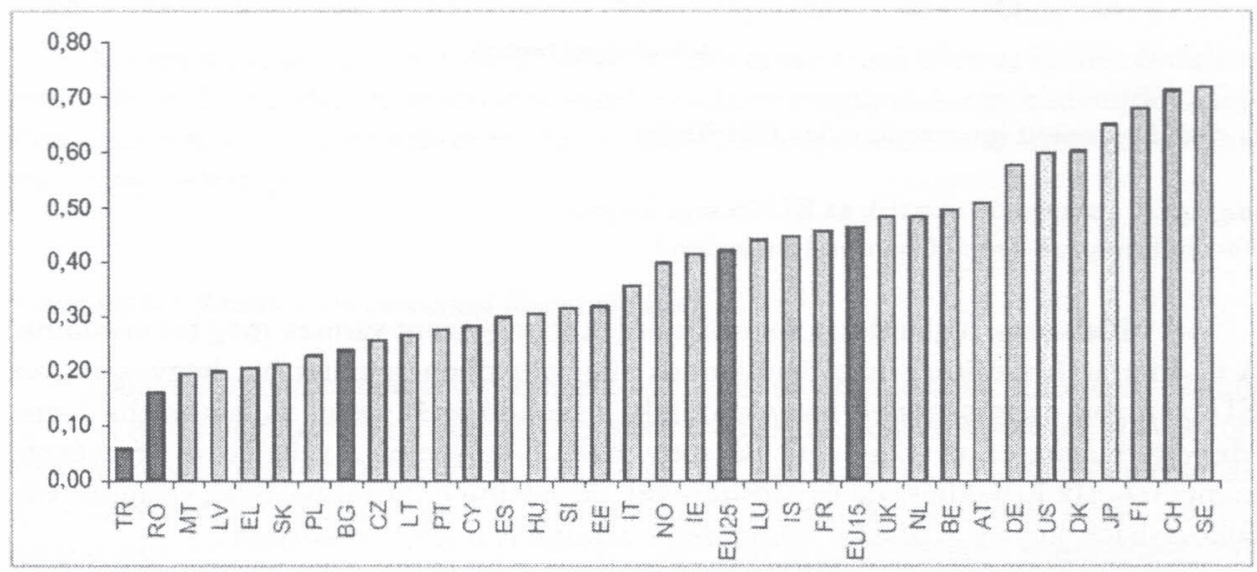

4. ábra. Összesített innovációs index, SII (2005)

Az EU Innovációs eredménytáblájának 2005. évi adataiból kiderül, hogy hazánk az SII-index alapján a tizenötödik helyet foglalja el a 25 EU-tagország között (4. ábra). Az európai innovációs trendek kimutatása (European Trend Chart on Innovation) összeveti az egyes országok $S I I$-adatait az $S I I$-értékek éves változásának mértékével (5. ábra). Hazánk összesített innovációs indexének abszolút értéke viszonylag alacsony, de gyorsan növekvố dinamikát mutat, így az úgynevezett „felzárkózó országok” mezônyében foglalunk helyet. 


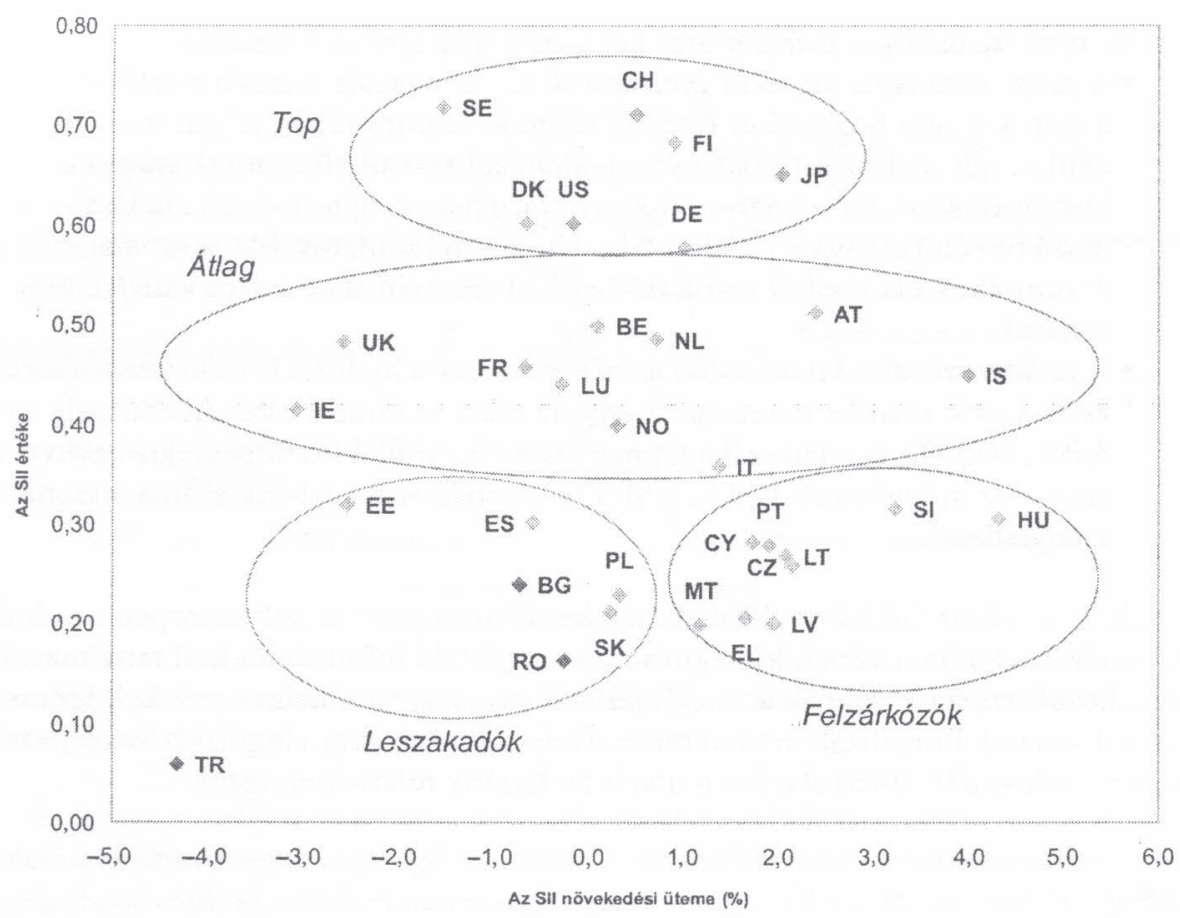

5. ábra. Összesített innovációs index (SII 2005)

Megjegyzés: a szaggatott vonalak az EU-25 szintjét jelzik.

Forrás: European Trend Chart on Innovation2

A vállalkozási hajlandóság fokozása érdekében viszont vannak még tennivalóink. A 6. ábra az összesített innovációs index függvényében mutatja be, hogy az egyes EU-országok népességének hány százaléka hajlandó saját üzleti vállalkozásba fogni. Magyarországon ez az arány elég alacsony. Ezen a helyzeten a vállalkozói készségek, kompetenciák kialakításával és erősítésével, társadalmi tudatformálással, valamint vállalkozásbarát jogi és gazdasági környezet kialakításával lehet változtatni.

${ }^{2}$ Lásd: http://www.trendchart.org/scoreboards/scoreboard2005/methodology.cfm 


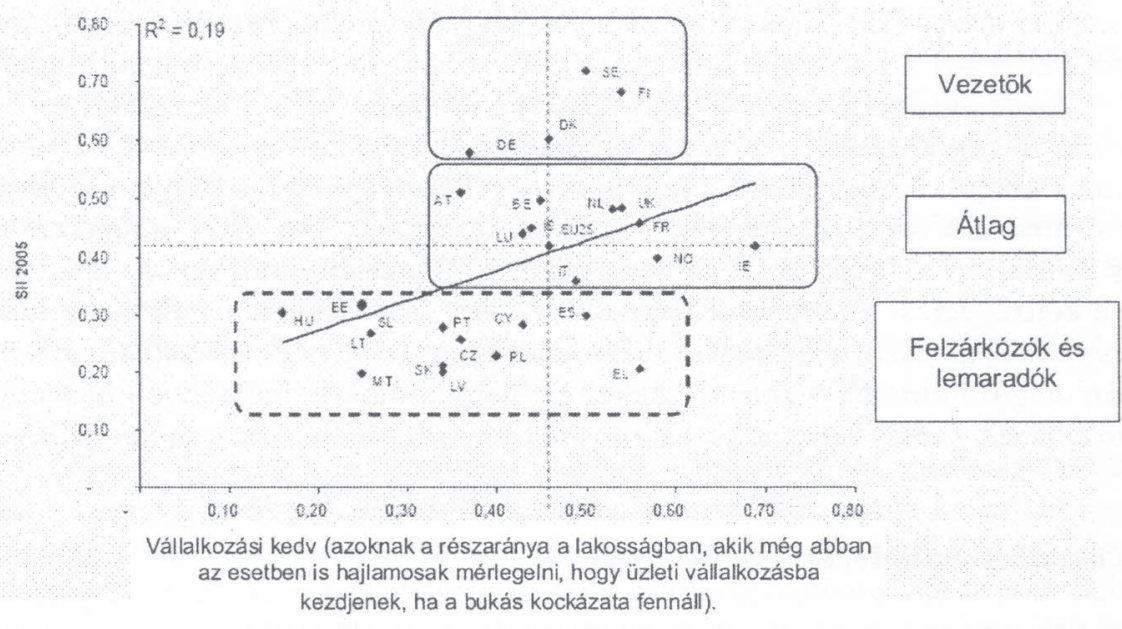

6. ábra. Az SII és a vállalkozási hajlandóság összefüggése

\section{Reformok a magyar innovációs rendszerben}

A magyar gazdaság versenyképességének növelése érdekében az elmúlt években elengedhetetlenné vált a nemzeti innovációs rendszer megújítása, egy kiszámítható fejlődési pálya kijelölése. Ennek érdekében 2003-ban megkezdődött az innovációs rendszer átfogó reformja.

\section{- A kutatás-fejlesztés és az innováció finanszírozása}

2003 novemberében törvény született a Kutatási és Technológiai Innovációs Alapról (KTIA). Az elkülönített állami pénzalap egyrészt a vállalatok befizetéseiból (ez az éves korrigált nettó árbevételnek elôször a 0,2\%-át, majd 0,25\%-át tette ki, 2006-ban pedig annak 0,3\%-a), másrészt ennek megfelelő összegú állami hozzájárulásból tevődik össze. Az alap forrásai így nem függnek az éves költségvetési alkuktól. A járulékfizetési kötelezettség alól mentesülnek a mikro- és kisvállalatok. A gazdasági társaságok a saját költségeikkel, valamint a költségvetési és nonprofit kutatóhelyektól megrendelt $\mathrm{K}+\mathrm{F}$ tevékenységek költségeivel csökkenthetik a befizetendő innovációs járulék mértékét. Ennek hatására az elmúlt egy évben 430-ról 630-ra emelkedett a K + F tevékenységgel foglalkozó vállalkozások száma. Ez javítja az állami és vállalati $\mathrm{K}+\mathrm{F}$ ráfordítások jelenlegi kedvezótlen arányát is.

\section{- A kutatás-fejlesztés és az innováció törvényi megerósitése}

A kutatás-fejlesztésról és a technológiai innovációról szóló 2004. évi CXXXIV. törvényt az Országgyúlés 2004. december 20-án fogadta el, és 2005. január 1-jén lépett ha- 
tályba. Ez az ország elsô innovációs törvénye, ami átfogóan meghatározza és számos intézkedéssel segíti a kutatás-fejlesztést, a technológiai innovációt, valamint az eredmények gazdasági és társadalmi hasznosítását. Fô intézkedései a $\mathrm{K}+\mathrm{F}$ és a technológiai innováció finanszírozására, a kutatási eredmények, valamint az ezekból keletkezett szellemi alkotások hasznosítására, az innovatív vállalatalapításra, a kis- és középvállalkozások innovatív tevékenységének megkönnyítésére és az innováció emberi erôforrásainak erősítésére irányulnak. A törvény egyik legfontosabb intézkedése, hogy csökkenti a költségvetési kutatóhelyek vállalkozásalapításának korlátait, és megteremti a kutatómunkában részt vevốk közvetlen érdekeltségét azzal, hogy a közalkalmazotti státuszban dolgozó kutatók - annak érdekében, hogy kutatási eredmények közvetlenül hasznosuljanak - részt vehetnek a hasznosító (spin-off) vállalkozások munkájában.

\section{- Az innovációpolitika kormányzati szereplối}

- A Tudomány- és Technológiapolitikai Kollégium (TTPK) a miniszterelnök vezetésével múködő legfelső kormányzati tudomány-, technológia- és innovációpolitikai fórum. A kollégium tevékenységét a tanácsadó, döntés-elókészítő, koordináló és értékelő testületként létrehozott Tudomány- és Technológiapolitikai Tanácsadó Testület segíti.

- 2004. január 1-jén országos hatáskörú kormányhivatalként megalakult a Nemzeti Kutatási és Technológiai Hivatal (NKTH). Az NKTH fő feladatai:-

- a kormányzati innovációs feladatok koordinációja;-

- az innováció regionális rendszerének fejlesztése - felkészülés az uniós strukturális alapok felhasználására;-

- a K + F-tevékenység hatásának követése és elemzése (stratégiai tervezés, hatáselemzés, innovációs adatbázisok kiépítése és kezelése);-

- az innovációs szemlélet terjesztése;-

- a tudásbázis és az üzleti szféra együttmúködésének erôsítése;-

- a K + F nemzetközi kapcsolatainak kezelése és fejlesztése.

- A Kutatási és Technológiai Innovációs Tanács az NKTH mellett múködô, stratégiai kérdésekkel foglalkozó testület. A Tanács a Hivatal elnökével együttmúködve állást foglal az Alap tervezésének, múködtetésének és felhasználásának stratégiai kérdéseiben.

- A Kutatás-fejlesztési Pályázati és Kutatáshasznosítási Iroda (KPI) 2003. augusztusában jött létre. A KPI-t az NKTH elnöke felügyeli. A KPI feladata a Kutatási és Technológiai Innovációs Alap, valamint az 1. Nemzeti Fejlesztési Terv Gazdasági Versenyképesség Operatív Programja K + F és innovációs programjainak menedzselése.

\section{KFI-stratégia}

A tudásalapú társadalom és gazdaság kialakításának időszakában a versenyképesség egyik meghatározó tényezôje a kutatás-fejlesztés és az innováció. A versenyképesség megốrzéséhez mind több tudományos és technológiai területen kell magas szintú 
tudást megszerezni, és ezeket az ismereteket új, piacképes termékekben, szolgáltatásokban megjeleníteni. A tudomány az emberi életminőség fontos tényezójévé vált.

A kutatás-fejlesztési és innovációpolitikai stratégia nemzeti stratégia, amely az országos fejlesztéspolitikai koncepció, valamint az EU strukturális alapok felhasználására készülő II. Nemzeti Fejlesztési Terv célkitűzéseivel összhangban készült.

A hazai kihívásokra stratégiai választ kell adni, amely középtávon meghatározza a célokat és a célok elérését szolgáló prioritásokat. A társadalmi egyeztetés fázisában lévő kormányzati kutatás-fejlesztési és innovációs középtávú stratégia kiemelten a gazdasági versenyképesség ösztönzését szolgálja. A stratégia idóhorizontja 2006-2013, összhangban az EU strukturális alapok elérésére készülő II. Nemzeti Fejlesztési Terv időtartamával.

A kutatás-fejlesztési és innovációs stratégia - összhangban a gazdaságpolitikai célokkal - a magyar gazdaság versenyképességének növelését, s ezen keresztül a magyar társadalom életminőségének javítását szolgálja. A stratégia általános célja az, hogy Magyarország 2013-ra olyan országgá váljon, ahol a gazdaság hajtómotorja az innováció, és a hazai érdekeltségú vállalatok versenyképes termékekkel jelennek meg a globális piacon.

A stratégia 2025-ig elôre tekintő jövóképet vázol fel. Magyarország 2025-re Európa fejlett tudásalapú gazdasággal rendelkezô, innovatív és versenyképes országa lesz, amely vonzó célpontja a szellemi és anyagi befektetéseknek. Innovációt ösztönzô gazdasági és jogi környezet segíti a magyar vállalatokat a nemzetközi piacon versenyképes termékek és szolgáltatások előallításában, a nemzetközileg elismert magyar tudásbázist az új ismeretek elóállításában és hasznosításában, valamint a képzett, kreatív magyar munkaerốt az alkotómunkában és az életen át tartó tanulásban, képzésben.

A stratégia középtávú céljai:

- Erósödjön a vállalatok kutatási és fejlesztési tevékenysége. A vállalatok Magyarországon történő $\mathrm{K}+\mathrm{F}$ ráfordítása legalább kétszerese legyen az állami ráfordításoknak. Az állami ráfordítás $0,7 \%$ legyen, a vállalati ráfordítás ennek kétszerese, 1,4\%. Az EU forrásainak hatékony felhasználásával a teljes nemzeti $\mathrm{K}+\mathrm{F}$ ráfordítási arány 2013-ra további 0,4\%-kal, legalább 2,5\%-ra növelhető. Olyan ösztönzố és támogatási rendszer múködjön, hogy a KKV-k és a nagyvállalatok fokozzák innovációs tevékenységüket, többszörözzék meg $\mathrm{K}+\mathrm{F}$ ráfordításaikat, valamint növekedjen a multinacionális vállalatok magyarországi kutató-fejlesztô egységeinek száma és $\mathrm{K}+\mathrm{F}$ célú befektetéseinek mértéke.

- Épüljenek ki nemzetközileg is elismert, nagy kapacitású $K+F$ és innovációs központok. Jöjjenek létre a világ élvonalába tartozó kutatóegyetemek és nemzeti kutatólaboratóriumok, amelyek szorosan együttmúködnek a vállalatokkal és rugalmasan reagálnak a gazdaság igényeire. Javuljanak az infrastrukturális feltételek. A költségvetési és a nonprofit szférában múködő kutatóhelyeken javuljon a minőség és a hatékonyság, erôsödjön az eredmények hasznosítása és a gazdasággal való kapcsolat. Nemzetközi együttmúködéssel, hálózatok szervezésével teremtốdjenek meg a hosszú távon versenyképes kutatási lehetôségek keretei.

- Erốsödjön a társadalmi versenyképességet megalapozó tudás. Legyenek biztosítottak a társadalmi és gazdasági szempontból jelentős alapkutatások feltételei. Tovább erősödjön a magyar kutatás versenyképessége. Valósuljanak meg a társadal- 
mi-gazdasági kihívások, a nemzeti értékek, örökségek kutatásai, valamint a vállalati szféra közvetlen érdekeltségébe nem tartozó közérdekú kutatási és fejlesztési programok. Erôsödjenek az új kutatási eredmények társadalmi és gazdasági adaptációs feltételei. Magyar kutatók vegyenek részt a nemzetközi együttmúködési hálózatokban, és kapcsolódjanak be az emberiség jövôjét érintô, új globális kihívások kutatásába. Növekedjen a hazai K + F + I szektor megtartó ereje a fiatal kutatónemzedék számára.

A stratégiai célok megvalósítása során az alábbi stratégiai alapelvek érvényesülnek:

- a szellemi és anyagi eróforrások koncentrálásával elkerülhetô az erôforrások szétaprózódása, elérhetốk a hatékonysághoz szükséges kritikus támogatási jellemzók,

- a K + F eredmények fokozott gazdasági és társadalmi hasznositása megalapozza a versenyképességet, valamint a piacképes termékek és szolgáltatások létrehozását,

- a régióban múködô vállalatok innovációs aktivitásának ösztönzése és az igényeikhez rugalmasan alkalmazkodó innovációs szolgáltató hálózatok kiépítése biztosítja a regionális innovációs stratégiák megvalósítását.

A stratégiában a következő horizontális szempontok érvényesülnek: foglalkoztatás, fenntartható fejlődés, kis- és középvállalatok, humáneróforrás, egészséges ember, infrastruktúra, informatika, nemzetközi együttmúködés, biztonság, esélyegyenlőség.

A stratégiai célok megvalósítását szolgálják az alábbi stratégiai jelentőségú beavatkozási területek számára biztosított prioritások:

- A globális piacon versenyképes hazai vállalkozások és termékek.

- Teljesitmény- és hasznositásvezérelt, hatékony nemzeti $K+F$ és innovációs intézményrendszer.

- A tudásalapú gazdaság és társadalom igényeinek megfeleló innovativ munkaeró.

- Kutatás-fejlesztést és innovációt ösztönzơ gazdasági és jogi környezet.

- A kutatási-fejlesztési tevékenységet és az innovációt befogadó társadalom.

A nemzeti stratégia kiemelt célokat és prioritásokat fogalmaz meg. A stratégia megvalósításának részletes feladatait és azok ütemezését a nemzeti kutatás-fejlesztési és innovációs akcióterv foglalja majd össze, amelynek kidolgozására a stratégia elfogadását követôen kerül sor.

\section{Az innováció regionális dimenziói}

A nemzeti innovációs rendszer elemei területileg egyenlótlenül fejlettek, ami kedvezốtlenül hat az egész nemzetgazdaság versenyképességére. A regionális innovációs rendszert az alábbi hiányosságok jellemzik: 
- Az egyetemi féróhelyek a lakosság megoszlásához képest túlságosan Budapesten koncentrálódnak, ami egyrészt a régiók versenyképességének leszakadását jelenti, másrészt akadályozza a gazdasági egyenlőtlenségek csökkentésére irányuló erófeszítéseket.

- Nem alakultak ki a kutatóhelyeket és a régiók vállalkozásait összekapcsoló hálózatok, a regionális klaszterek.

- Az innovációs vállalkozásfejlesztő szervezetek, innovációs hídképző intézmények hiánya elsôsorban a régiókban érezteti hatását. A tudás és a technológiai újítások lassú terjedéséból következốen a jelentôsebb kutatóhelyek tudományos eredményei nem tudnak innovatív termékek és a szolgáltatások formájában megjelenni a régiókban.

- A regionális gazdaságfejlesztés, a munkahelyteremtés, a régiók versenyképességét meghatározó kis- és középvállalatok innovációs képessége különösen gyenge.

- Kevés az újonnan alakuló technológiaintenzív vállalkozás, igen kevés spin-off jellegú vállalkozás alapul az egyetemek, a kutatóintézetek eredményein.

- Végül a legalapvetốbb rendszerszintú hiányosság az együttmúködési készség fejletlenségére vezethetố vissza. Hiányzik az a kulturális kapocs, amit a technológiai, valamint az üzleti esélyek és kockázatok értékelése biztosíthatna, összehozva a tókehiányról panaszkodó ötlettulajdonosokat a projekthiányra panaszkodó befektetókkel. Ugyanígy gyenge a kutatási és a vállalkozói szféra közötti együttmúködés. Ennek az egyik megnyilvánulása, hogy alig vannak tudáscentrumokból „kirajzó”, az ott elért eredményeket hasznosító vállalkozások. Fejletlen a technológiai inkubáció.

Az elmúlt két évben kiemelt figyelmet kapott a régiók innovációs képességének növelése. A régiók fejlődésének ösztönzése érdekében a KTI Alap 25\%-át regionális innovációs célokra kell felhasználni.

Az NKTH megalakulásakor a régiók innovációs képességének fejlesztése érdekében az elsố lépés egy stratégiai koncepció kidolgozása volt. 2004-ben két program indult meg a tudás létrehozásában és közvetítésében szerepet játszó intézmény- és eszközrendszer kialakítására és a feltételek biztosítására. A Pázmány Péter-program célja az egyetemek kutatás-fejlesztési eredményeinek hasznosítása és az iparral való intenzív együttmúködés révén regionális egyetemi tudásközpontok (RET) létrehozása. A $B a$ ross Gábor regionális innovációs fejlesztési programot 2004-ben indította el az NKTH. A program az innováció ösztönzésével támogatja a magyarországi régiók gazdaságának és versenyképességének fejlesztését. Céljai a régiók gazdaságának és versenyképességének innováción alapuló fejlesztése, a regionális innovációs hálózatok kialakítása és megerôsítése, valamint a regionális innovációt ösztönzố intézkedések decentralizálása. A program egyik legfontosabb eleme a regionális innovációs ügynökségek hálózatának kialakítása, amely a 2004. év vége óta információkkal és különféle innovációs szolgáltatások kínálatával segíti a kutatás-fejlesztési és a vállalkozási szféra együttmúködését. A Baross Gábor-program másik fontos elemeként 2005. júniusában meghirdetett Innocsekk program célja a regionális innováció szereplói közötti kapcsolatrendszer erôsítése, a mikro-és kisvállalkozások innovációs kezdeményezéseinek támogatása és a regionális innováció eszköztárának bốvítése az innovációs szolgáltatások támogatási rendszerének 
bevezetésével. Szintén a Baross-program keretében valósul meg a regionális innovációs fejlesztések programcsomagja, ami lehetôséget ad a régiók számára, hogy a helyi viszonyok ismeretében maguk határozzák meg fejlesztési prioritásaikat, és kézbe vegyék saját sorsuk alakítását. A régiók aktivitásától függ, hogy milyen mértékben részesülnek a Technológiai Innovációs Alap regionális forrásaiból, és azokat hogyan hasznosítják versenyképességük javítására.

A meglévő problémák megoldását egy fejlettebb innovációs szolgáltató intézményrendszer segítheti. A rendszer hatékonysága attól függ, hogy mennyire tud együttmúködni a vállalkozásokkal és a befektetókkel, és hogyan integrálódik a kutatás-fejlesztés nemzeti kontextusába. Annak érdekében, hogy a regionális hálózat megfelelően töltse be szerepét a hazai tudástranszfer terén, szükséges a regionális innovációs kapacitás fejlesztése a regionális innovációs intézményrendszer megerôsítésével, az innováció térbeli terjedésének elôsegítésével, decentralizált innovációs programok múködtetésével, valamint a regionális innováció informatikai feltételeinek javításával és emberi erôforrásainak fejlesztésével.

Összegezve: megállapítható, hogy csak akkor indulhat meg a területi felzárkózás, ha a politikai döntéshozók a szubszidiaritás elve alapján több hatáskört és felelôsséget ruháznak a régiókra, és biztosítják a szükséges fejlesztési eszközöket és forrásokat. Az a régió lehet sikeres, ahol a magas hozzáadott értéket képviselő ágazatok jelen vannak. Mindebben megkülönböztetett helye lehet a tudásiparnak. A tudásipar fejlődésében fontos szerepe van az emberi eróforrásoknak, az infrastruktúrának, az intézményi háttérnek, valamint az együttmúködési hálózatoknak. A célok megvalósításának elengedhetetlen feltétele az állami szerepvállalás mellett a helyi innovációs szereplók szoros együttmúködése is. 